\title{
GRAMMATICAL AND DISCOURSE COMPETENCE ANALYSIS IN WRITING
} ARGUMENTATION PARAGRAPH

\author{
Linda Aprillianti \\ Diponegoro University, Indonesia \\ (lindaaprillia29@gmail.com)
}

Received: $16^{\text {th }}$ September 2019; Revised: $24^{\text {th }}$ November 2019; Accepted: $28^{\text {th }}$ December 2019

\begin{abstract}
Writing is a form of embodiment of indirect communication. It is required to pay attention to the structure associated with the elements of writing so that readers can understand the message conveyed by the writer. This study is intended to identify the grammatical and discourse competence of the students in writing argumentative paragraphs. The research used was qualitative descriptive approach with analytical method. The data of this study were taken from the students' assignment papers related to writing argumentative paragraph in Komunitas Cerdas Course. There were twenty task sheets resulting from students' writings. All of this data were analyzed in terms of grammar and discourse. The data collection techniques used was written tests. In analyzing the data, the writer used the theory of Miles and Huberman, so the form of study was given in short description. The results of the analysis showed that students already had sufficient competence in grammar or discourse, further, in general, the students already had grammatical competence and sufficient discourse competence. However, there were some aspects in grammar that needed to get more attentions, such as the ability of the students to arrange words into good sentences.
\end{abstract}

Key Words: grammatical competence; discourse competence; writing skill; argumentatif paragraph

\section{ABSTRAK}

Menulis adalah bentuk perwujudan komunikasi tidak langsung. Hal ini diperlukan untuk memperhatikan struktur yang terkait dengan unsur-unsur penulisan sehingga pembaca dapat memahami pesan yang disampaikan oleh penulis. Penelitian ini dimaksudkan untuk mengidentifikasi kompetensi gramatikal dan wacana siswa dalam menulis paragraf argumentatif. Penelitian ini juga memberikan koreksi kesalahan siswa dalam menulis paragraf argumentatif. Penelitian ini menggunakan pendekatan deskriptif kualitatif dengan metode analitik. Data penelitian ini adalah kertas tugas siswa terkait dengan menulis paragraf argumentasi di Kursus Komunitas Cerdas. Ada dua puluh lembar tugas yang merupakan hasil tulisan siswa. Semua data ini dianalisis dalam hal tata bahasa dan wacana. Teknik pengumpulan data yang digunakan adalah tes tertulis. Teknik analisis data, penulis menggunakan teori Miles dan Huberman, sehingga bentuk penelitian diberikan dalam deskripsi singkat. Hasil analisis menunjukkan bahwa siswa sudah memiliki kompetensi yang cukup dalam tata bahasa atau wacana. Berdasarkan hasil analisis, secara umum siswa sudah memiliki kompetensi tata bahasa dan kompetensi wacana yang cukup. Tetapi ada beberapa aspek dalam tata bahasa yang perlu mendapat perhatian lebih, sedangkan kompetensi wacana, kemampuan siswa untuk mengatur kata-kata menjadi kalimat yang baik masih perlu banyak peningkat.

Kata Kunci: kompetensi tata bahasa; kompetensi wacana; keterampilan menulis; paragraf argumentasi

How to Cite: Aprillianti,L. (2019). Grammatical and Discourse Competence Analysis in Writing Argumentation Paragraph. IJEE (Indonesian Journal of English Education), 6(2), 133-142. doi:10.15408/ijee.v6i2.11944 


\section{INTRODUCTION}

The basis of studying a language is broadly related to the components of the target language such as vocabulary, grammar, and pronunciation, which are the basis for mastering skills of language like reading, listening, speaking and writing. Writing is one of the most complicated and difficult skills for students to master. Students are asked to produce letters, words, and sentences that can be understood by the reader. In writing, students should be able to effectively select topics, to plan, and to organize ideas. Some problems may occur because both ESL and EFL students do not have enough vocabulary, afraid of criticism, and want to avoid emotional confusion when they encounter empty topics and papers.

The teaching process of writing requires more thought and consideration than the speaking teaching process. Therefore, in the English department, writing teaching is done gradually. Writing skills are said to be difficult because they involve aspects such as organization, grammar, vocabulary, technical writing and punctuation, and ideas or ideas to be exposed. In class practice, students often complain that writing assignments are very difficult. So that, this study is to provide an analysis on student's language errors in their writing skill. Brown (2007, p.105) described that the error analysis is an analysis of the language errors of a student in either a foreign language, a second language, or a language in general. Thus, it can be said that the definition of language error analysis is a process of work used by teachers and researchers of the language with the steps of data collection, identification of errors contained in the data, explanation of the error, the classification of errors based on the cause, and evaluate the level of seriousness of the error. In fact, mastery of the material is the basic purpose of teaching and learning process. Mastery of the material is also often used as a primary consideration to measure the success of a lecturer in teaching.

Based on the above mentioned background, the writer wants to do a study related to writing competence. This study aims to assess and identify students' ability in writing argumentative paragraph. In this study, the author identified the student's writing skills in making argumentative paragraph by using English. The argumentative paragraph is a paragraph which main idea is developed by exposing the opinions, reviews, subject and personal ideas of the author. The purpose of the argumentative paragraph is to convince 
and influence the reader to have an opinion similar to the author's opinion. The writer obtained this data by assigning tasks to 20 students from Komunitas Cerdas course to make an argumentative paragraph according to the topics of articles below:

\section{Education for Women}

2. The Influence of Instagram for teenagers

3. The Impact of Gossip Account in Social Media

In this study, the writer tried to analyze the ability of the students in using tense and word order as a form of realization of their grammatical competence. Besides, in discourse competence, the authors analyzed their ability to use coherence and cohesion, as well as unity and completeness. Brown (1987, p.199-200) adds that communicative competence consists of four types of competence: grammatical competence, contextual (Discourse) competence, sociolinguistic competence, and strategic competence).

Grammatical competence is the ability at the stage of a sentence. So this is related to the ability of students to be able to make / arrange the sentences properly and correctly in accordance with the rules. Then, contextual or discourse competence relates to the ability of combining some sentences into a larger form, the paragraph. This study is expected to give practical contribution to the growth of knowledge in learning and teaching of English especially writing skill. So, the teacher will know the ability of students who can be used as one of the benchmarks to provide the appropriate, effective, and efficient teaching materials, . Hence, the focus of this study is to assess and identify the competence of grammar and discourse in writing argumentative paragraphs.

\section{Writing Skill}

There are four important skills in English namely listening, reading, speaking and writing. To improve our English skill, the first step we should be taken is to listen, then to read, then to speak and the last is to write. By looking the arrangement of step in learning English, it can be said that writing skill is the most difficult skill in English. It is because, the learners cannot make writing without passing listening, reading and speaking stage first. In writing a sentence or a paragraph, the learners need to pay attention on this following conditions: 1) The use of capital letter at the beginning of sentence; 2) Pay attention on punctuation; 3) Spelling rules; 4) Abbreviations; 5) Sign and symbol.

In addition, in writing a paragraph or even a paper, the writer should be 
aware of some following points: 1) Plagiarism; the writer should paraphrase the sentence in order to avoid plagiarism; 2) Sentence varieties; a good writing should be able to attract the reader's attention. Therefore, the writer needs to avoid boring sentences that all seem the same.

\section{Argumentative Paragraph}

An Argumentative paragraph is a paragraph, which is written in order to persuade someone to agree with your writing. In another purpose, argumentative paragraph is used when we are arguing for claim or against something. Argumentative paragraph is similar with expository paragraph. An argumentative paragraph consists of following points: 1) Claim, it explains what to argue about the topic; 2) Evidence deals with an example to support the claim; 3) Link is used to explaining the evidence

\section{Grammatical and Discourse Competence}

A person, who has a language competency, is a person who has language skills. Language skills are the skills of a person using adequate language seen from the language system. Canales and Swain (1980, p.29), propose the theory of communicative competence which minimally includes three main competencies: Grammatical, Sociolinguistic and Strategic competencies. Grammatical competence is the ability to use language forms (sounds, words, and sentence structure). Grammatical competence is the ability at the stage of a sentence. So this is related to the ability of students to be able to make / arrange the sentences properly and correctly in accordance with the rules. Refinita (2014) has done the research related to grammatical problem. She has analyzed the university students' grammatical problem in writing simple paragraphs. Based on her result, the lack of grammatical competency and language carelessness may academically give bad effects to the quality of sentence constructions written by EFL learners, particularly in Indonesian context. I fully agree with the result; however we cannot focus on grammatical competence only; discourse competence also needs to be noticed. Then, the role of the teachers also greatly influence student's development.

If Canales and Swain divided communicative competence into three categories, Celce-Murcia, Dornyei and Thurnell formulated communicative competence as a unity of competence consisting of five aspects of competence namely discourses, linguistic, socio-cultural, and strategic. In this model, discourse competence is a core competency that connects competence to other competencies. 
Discourse Competence is the ability to understand and create longer forms of language from sentences, such as stories, conversations, or business letters. Discourse competence includes understanding how specific examples of language use are built internally. The discourse competence also includes an understanding of how the text relates to the context or situation in which they are used.

\section{METHOD}

The research used qualitative descriptive approach with analytical method. Creswell (1994) said that qualitative research is descriptive because researchers are interested in the process, meaning, and understanding through words or images.

The data of this study was students' assignment papers related to writing argumentative paragraph in Komunitas Cerdas Course. There were twenty task sheets taken from the students' writings. The students are asked to write a paragraph argumentation by selecting one of the topics that have been provided by the writer. It conducted to find out and measure the initial skill of writing argumentation paragraphs.

In analyzing data, the writer used analysis model of Miles and Huberman.
Miles and Huberman (1994) argued that the activity in qualitative data analysis is done interactively and continuously to complete, so the data is saturated. The activities in data analysis namely: data reduction, display data, and draw conclusion. The first activity, the writer summarized, chose the essentials, focused on the important things, and discarded the unnecessary data. After the data were reduced, the writer displayed them. in the form of a brief description. After obtaining the results of reduction and data display, the writer made a tentative conclusion. Then did the verification so that the results of the analysis can be accountable and lastly wrote the final conclusion.

\section{RESULTS AND DISCUSSION}

\section{Grammatical Competence}

In this study, the writer aims to measure students' discourse competence, by analyzing the students' ability to use correct grammar. From seven students the writer found many problems in the grammar they used when creating argumentative paragraphs. 


\section{Omission}

The results indicated that omission was the most common types of grammatical problems made by the students. Some of the omission can be categorized as "silly mistakes.". The followings are some examples of the omission:

\section{Missing article:}

1. Error:_Lot of gossip accounts that are not clear who the owner is.

Revised: a lot of gossip accounts that are not clear who the owner is.

2. Error:_Public figure who talking about feel dislike

Revised: a public figure who is talking about feel dislike

3. Error: Instagram is known as _ most popular social media platform nowadays.

Revised: Instagram is known as the most popular social media platform nowadays.

4. Error: Instagram is_ application that you can share some photos to your followers.

Revised: Instagram is an application that you can share some photos to your followers.

\section{Missing be:}

1. Error: Public figure who talking about feel dislike
Revise: a public figure who is talking about feel dislike

2. Error: Many people still thinking that woman does not need to get a good education

Revise: Many people are still thinking that woman does not need to get a good education

Omission, in the form of omitting articles and be, was also frequently made by the university students.

\section{Misplacement}

Another type of grammatical problems made by the students in their argumentative paragraphs is misplacement. It may appear also as the grammatical interference of first language of the students. These are the examples of misplacement found in students 'argumentative paragraphs.

1. Error: account gossip does not fully have negative impact

Revised: gossip account does not fully have negative impact.

2. Error: on Instagram, we can also find pornographic photos or videos

Revised: on Instagram, we also can find pornographic photos or videos

Addition is another type of grammatical problems, which was also frequently made by the students. It seems that this type of grammatical 
problems was influenced by their language habits in using particular words. The followings are the examples of addition made by students in their writings.

1. Error: Instagram has a various content

Revised: Instagram has many contents

2. Error: They could get a new friend from following people all around the world

Revised: They could get new friends from following people all around the world

\section{Miscellaneous}

The last type of grammatical problems made by the students in their simple paragraphs is miscellaneous. It seems that they thought in their own L1 then wrote in English with less attention to English grammar. The followings are some examples of miscellaneous types of grammatical problems.

1. Error: Teenagers will suffer, depression and started changing themselves becomes insecure person.

Revised: Teenagers will suffer, depress and change them into insecure person.
2. Error: When the teenagers have addicted playing Instagram they will feeling lazy to interact directly.

Revised: When the teenagers have addicted to play Instagram, they will feel lazy to interact directly.

3. Error: Instagram can also causes an impact that positive or negative.

4. Revised: Instagram also can give positive or negative impact.

Based on the results above, it can be argued that the students 'grammatical problems were mostly caused by lack of grammatical competence and language awareness in English. Consequently, the students could not write grammatically correct sentences as required; such kinds of ungrammatical sentences may come to problems in written English. In other words, it can be reasonably stated that the students were academically lack of grammatical competency.

\section{Discourse Competence}

To measure students ' discourse competence, the writer analyzes students' ability to use coherence, cohesion, unity, and completeness within their argumentation paragraphs. An example of this error can be seen in the following example: 
Error: In Instagram too, you can apply filters to your photos and many other interesting feature.

The above sentences are not well structured, thus making the reader confused with the intent of the sentence. It should be like this:

Revised: Through the Instagram, you can add some filters and any other interesting features in your picture.

Based on the sentence above, it proves the lack of ability of students in using coherence. Next cases are related to cohesion, the most common problem of cohesion of students in their writing is the error in using pronouns. This can be seen in the example as below:

Error: Those accounts have a lot of followers, but it only discusses about gossip, facts, and the latest public figure activity in Indonesia.

'In the sentence above, we can see that the sentence uses wrong pronoun to replace the subject "those accounts". The correct sentence should be like this:

Revised: Those accounts have a lot of followers, but they only discuss gossip, facts, and the latest public figure activity in Indonesia.

The subject "those account" must be replaced with pronouns "they" because it is plural. For completeness, the students already have sufficient capability, because there is no mistake in completing the paragraph they have written.

The last problem that is faced by these university students in making argumentative paragraph is unity. For ability to use unity, the error that occurs is the absence of "topic sentence" and the use of unusual words. Examples of such errors can be seen in the example of the following example:

Error: Mother is the first teacher for her children. Every woman wants to be a mother. The education is important because someday she will teach her children......

The topic that is selected entitled "The important of Education for Women", but the sentence did not contain the topic in accordance with the title selected. This proves that there are still some students who do not know how to write good and correct paragraphs. The example can be seen as follows:

Error: Now, a lot of gossip accounts that are not clear who the owner suck netizen attention.

From that sentence, there are so many unusual words to use. Other than that the sentence structure is not arranged correctly and there are many other errors. So in my opinion, the sentence should read as follows: 
Revised: Now, there are many unknown gossip accounts is attracting the attention of social media users.

In the sentence, the students used the word "suck" to explain that the gossip accounts have big influence to social media users. The word "suck" can be replaced with the word such as "attract or arrest.". The for the word "netizen", we can use the word "social media users" because the word is a slang word that not all people use.

\section{CONCLUSION}

In general, the students in this study already have grammatical competence and sufficient discourse competence. But there are some aspects in grammar that need to get more attention, while the discourse competence, the ability of students to arrange words into good sentence still need a lot enhancement. Another problem is that the limited vocabulary makes the students confused and difficult to choose which word is appropriate to be used in the context. Learning English vocabulary mastery, especially verbs, is very important for communication both oral and written.

\section{REFERENCES}

Brown, H. D. 2007. Principles of Language Learning and Teaching. Englewood Cliffs, N. J: Prentice-Hall.
Canale, M and Swain, M (1980) Theoretical bases of communicative approaches to second language teaching and testing. Applied Linguistic, 1, 1-47.

Celce-Murcia, M., Z. Dornyei, S. Thrurrel. 1995. Communicative Competence: A Pedagogically Motivated Model with Content Specifications. In issues in Applied Linguistics, 6(2), PP 5-35.

Creswell, J. W. 1994. Research Design: Qualitative and Quantitative Approaches London: SAGE Publications.

Hymes, D (1971) On Communicative Competence in Pride and Holmes (eds) (1972) Sociolinguistics. London: Penguin

Miles, MB. \& Huberman, AM. (1994). Qualitative Data Analysis (2nd edition). Thousand Oaks, CA: Sage Publications.

Refinita,Lely (2014). 'Students' Grammatical Problems in Writing Simple Paragraphs: Lack of Grammatical Competency Or Language Carelessness?" Proceedings of ISELT FBS Universitas Negeri Padang vol 2

Azar, Betty Schramfer. 2000 . "Understanding and Using English Grammar 3rd edition". CLRC Writing Center. Longman.

Hartanti, P. 2010. “Analysis of grammatical errors in Writing". Wikipedia (online), http://en.wikipedia.org/wiki/writin $\mathrm{g} / \mathrm{ht} \mathrm{m}$. Accessed on June 14, 2019

Gay, L. R. 1987. “Educational Research : Competencies for Analysis and Application. (3 th ed)". Ohio : Merill Publishing Company 
Richards, CJ and Renandya, WA. 2002. "Methodology in Language Teaching". Cambridge : Cambridge University. https://mrwestrup.weebly.com/argument ative-paragraph.html (access on June 14th, 2019)

https://learnenglish.britishcouncil.org/skil ls (access on June 14th, 2019). 